\title{
CERTAIN WAYS OF PROVING THE CRIMINAL OFFENCE OF AGGRAVATED LARCENY, WITH SPECIAL REFERENCE TO THE SUSPECT'S INTERROGATION PURSUANT TO ARTICLE 208A OF THE CODE OF CRIMINAL PROCEDURE*
}

\author{
Mirjana Kondor - Langer, PhD, Assistant Professor \\ Police College in Zagreb \\ Avenija Gojka Šuška 1, Zagreb, Croatia \\ mklanger@fkz.hr
}

\section{Stjepan Gluščić, PhD, Assistant Professor}

Police College in Zagreb

Avenija Gojka Šuška 1, Zagreb, Croatia

sgluscic@fkz.hr

\begin{abstract}
According to available data (statistical data, data from investigations, professional and scientific papers) property crime represents about two thirds of total crime in the Republic of Croatia. Proof of committing is very often based on personal sources of evidence and a significant number of criminal charges filed by the police with these criminal offenses are submitted to the State Attorney's Office. This article presents the state of affairs and trends of property crime, the way of proof, and analyzes the police's success in detecting and proving serious offenses (Article 229. of the Criminal Code). The work is based on the collected data from the police records of Aggravated Larceny crimes, with special emphasis on the suspect's interrogation based on Article 208a of the Criminal Procedure Act and the significance of the evidence thus obtained for proving the perpetration of the criminal offense. The research was conducted with the aim of determining the effects of the recently transposed Directive 2013/48/EU of the European Parliament and of the Council of 22 October 2013 on the right of access to a lawyer in criminal proceedings and in European arrest warrant proceedings, and on the right to have a third party informed upon deprivation of liberty and to communicate with third persons and with consular authorities while deprived of liberty (OJ L 294) into the criminal justice system of the Republic of Croatia.
\end{abstract}

Keywords: aggravated larceny, dismissal of criminal charges, evidence, interrogation of the suspect

The research for this publication was done as part of the scientific research project of the Police College in Zagreb: the impact of the Amendments to the Criminal Procedure Act on detection, clarification and prosecution of criminal offenses in the area of general criminality 


\section{INTRODUCTION}

According to the data of the Ministry of the Interior of the Republic of Croatia for 2018 , property crimes amount to $68.6 \%$ of the general crime. The criminal offense of aggravated larceny is the most common criminal offense in the field of general crime $(29.3 \%)$ and in these criminal offenses, in $95.7 \%$ of cases the perpetrator is unknown at the time of reporting. The feature of this criminal offense is that it was the most widely reported criminal offense in 2018, as well as the third most resolved criminal offense, after the criminal offence of threat and theft. ${ }^{1}$

The criminal offence of aggravated larceny is described in art. 229. of the Criminal Code (Official Gazette of the Republic of Croatia, No. 125/11, 144/12, 56/15, $61 / 15,101 / 17,118 / 18$, hereinafter CC). The research conducted in this paper shows, that in the Republic of Croatia, in the year 2018, the majority of incidences of aggravated larceny were committed in the manner described in art. 229. para 1. pt 1. CC (by breaking open, burglary or overcoming major obstacles) and then in the manner described in para. 1. pt. 2. of the same Article of the CC ("in a particularly dangerous" or "particularly impudent manner"). The third most common way of perpetration of aggravated larceny was by exploiting a situation caused by fire, flood, earthquake or other accident (Art. 229. para. 1. pt. 3. CC), and then, aggravated larceny where the value of the stolen property is small (Art. 229. para. 3. CC). The least common, with equal relative shares, was aggravated larceny committed in the manner that is described in art. 229. para. 1. pt. 6. and para. 2. of the CC.

Ministry of the Interior of the Republic of Croatia, General Secretariat, Department for Strategic Planning, Analysis and Development, Survey of Basic safety Indicators for year 2018., [https://mup. gov.hr/UserDocsImages/statistika/2018/Statisticki\%20pregled\%20temeljnih\%20sigurnosnih\%20 pokazatelja\%20i\%20rezultata\%20rada\%20u\%202018.\%20godini.pdf] Accessed 18.03.2019, p. IX, XXIV and 69 
Graph 1. Criminal offense of aggravated larceny

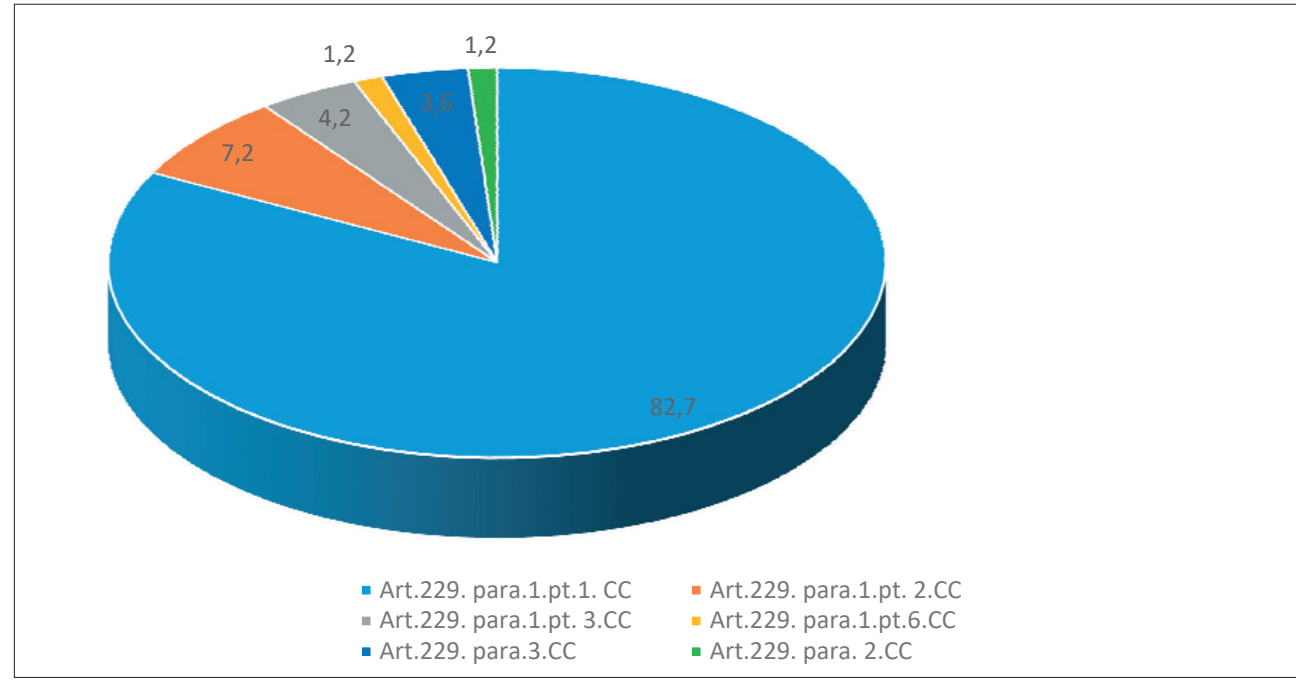

Source: authors' research

In the cases of criminal offenses against property, and thus in the criminal offence of aggravated larceny, relatively often the filing of criminal charges against the perpetrator was based on personal sources of evidence ${ }^{2}$. In the context of collecting information from the suspect there was a significant turnover that came about in 2017, specifically via the last Amendments of the Criminal Procedure Code (Official Gazette of the Republic of Croatia, No. 70/17) that has transposed the Directive 2013/48/EU of the European Parliament and of the Council of 22 October 2013 on the right of access to a lawyer in criminal proceedings and in European arrest warrant proceedings, and on the right to have a third party informed upon deprivation of liberty and to communicate with third persons and with consular authorities while deprived of liberty (OJ L 294, hereinafter referred to as Directive 2013/48/ EU) ${ }^{3}$, into the Croatian procedural law. From $1^{\text {th }}$ december 2017, police officers can no longer conduct informal interrogations of suspects. Therefore, in all situations where there is reasonable doubt that a criminal offense has been committed by a particular person, the police officers can only formally interrogate them. Thus, art. 208a of the Criminal Procedure Code

2 The division of evidence into personal and material, is one of the older divisions that is encountered in criminal investigation. In this paper we use it to highlight the significance of the suspect's testimony for criminal proceedings. About criminal evidence and different categorisation see: Karas, Ž.; Štrk, D., Izdvajanje nezakonitih materijalnih dokaza u poredbenom kaznenom postupovnom pravu, Zagrebačka pravna revija, Vol. 2, No, 2, 2013, p. 185 - 212; Deljkić, I. Heurističke i silogističke determinante istraživanja alibija u Kantonu Sarajevo, Kriminalističke teme 3-4, 2010, p. 99. - 117.

3 [http://eur-lex.europa.eu/legal-content/HR/TXT/PDF/?uri=CELEX:32013L0048\&from=HR] Accessed 01.03.2019 
(Official Gazette of the Republic of Croatia, No. 152/08, 76/09, 80/11, 91/12 Decision Constitutional Court of Croatia, 143/12, 56/13, 145/13, 152/14 and $70 / 17$, hereinafter CPC) formalizes the interrogation of suspects by determining the content of the instruction sent to the suspect regarding prior interrogation, the contents of the instruction that is given before the interrogation, clear warnings about the right to a defense attorney, the course of the interrogation and the information about recording of such interrogation, as well as the consequences arising from the violation of this prescribed manner of interrogation of the suspect (Gluščić and Kondor-Langer, 2018).

After the transposition of Directive 2013/48 / EU into the Croatian procedural law, the question arises as to whether the number of criminal reports dismissed by the State Attorney's Office has increased if the application does not give rise to a grounded suspicion that the suspect has committed the reported criminal offense (Art. 206. para. 1. pt. 4. CPC).

According to the data of the Ministry of the Interior of the Republic of Croatia for the year 2017, it is clear that in the territory of the Republic of Croatia in that year, 3011 cases of aggravated larceny were solved. In the same year there were 796 dismissals for the mentioned criminal offense, while the relative share of the dismissal on the basis of art. 206. para. 1. pt. 4. The CPC in relation to the total number of cases of committed aggravated larceny was $10.8 \%{ }^{4}$.

In 2018, the total number of solved cases of aggravated larceny amounted to 2626, with a total of 620 dismissals for the mentioned criminal offense. Relative share of dismissal under art. 206. para.1. pt. 4. The CPC in relation to the total number of cases of committed aggravated larceny was $11.1 \% .{ }^{5}$ From the data for these two years, in relation to the total number of cases of committed aggravated larceny for each particular year, it is evident that in 2018 there was a slight increase in the number of dismissals based on art. 206. para. 1. pt. 4. CPC. However, in order to make relevant conclusions in this area, it is necessary to cover a longer period of time, and it is necessary to wait for another year of application of the CPA de lege lata.

4 Ministry of the Interior of the Republic of Croatia, General Secretariat, Department for Strategic Planning, Analysis and Development, Survey of Basic safety Indicators for year 2018, [https://mup. gov.hr/UserDocsImages/statistika/2018/Statisticki\%20pregled\%20temeljnih\%20sigurnosnih\%20pokazatelja\%20i\%20rezultata\%20rada\%20u\%202018.\%20godini.pdf] Accessed 18.03.2019, p.115

5 Ministry of the Interior of the Republic of Croatia, General Secretariat, Department for Strategic Planning, Analysis and Development, Survey of Basic safety Indicators for year 2018, [https://mup.gov.hr/ UserDocsImages/statistika/2018/Travanj/Statisticki\%20pregled\%202017.pdf] Accessed 08.05.2019, p.111 
Just prior to the entry into force of the last Amendments of the Criminal Procedure Code, Ivičević Karas, Burić and Bonačić (2016 and 2016a) dealt with the improvements of the procedural rights of suspects and defendants in criminal proceedings, through the prism of European legal standards and defense rights, at various stages of Croatian criminal proceedings. Furthermore, both Burić and Karas (2017) discussed the dilemmas linked to the new definition of the suspect and the conduct of their interrogation.

After the entry into force of the last Amendments to the Criminal Procedure Act, Novokmet and Vinković (2018), elaborated upon the interrogation of the suspects in the Republic of Croatia after the implementation of Directive 2013/48/ EU, and Gluščić and Kondor-Langer (2018) conducted a study of the impact of the Amendments to the Criminal Procedure Act on detection, clarification and prosecution of criminal offenses in the area of general criminality, while Klier, Kondor-Langer and Glušcić (2018) conducted a research into police and state attorney's practices regarding interrogation of the suspect.

In order to gain a better insight into certain practical aspects of the investigation of criminal offenses of aggravated larceny, this paper presents some specific actions conducted by the police officers during the investigation of those criminal offences. In addition to the particular evidentiary actions that are being conducted after learning of the perpetration of the criminal offense of aggravated larceny, in the paper, the interrogation of the suspect on the basis of art. 208a CPC, as well as the evidentiary actions that police officers conduct during the interrogation of the suspect, are specifically emphasized.

\section{METHODOLOGY OF RESEARCH}

\subsection{The goal of the research}

The aim of the conducted research is to gain insight into certain ways of proving the criminal offenses of aggravated larceny, with special reference to the suspect's interrogation, based on art. 208a of the CPC and the significance of such evidence to prove the perpetrated criminal offense. The research was started based on the following two hypotheses:

H1: In the case of the commission of aggravated larceny, other than the suspect's interrogation pursuant to art. 208a CPC, there is little other material evidence

$\mathrm{H} 2$ : A relatively small number of suspects consume their right to a defense attorney during the interrogation pursuant to art. 208a CPC. 


\subsection{Sample}

Secondary sources of data were used for the survey sample, as well as the collected police records of the criminal acts of aggravated larceny committed on the territory of the Republic of Croatia during 2018.

During the research, a simple random sample was used and a total of 167 criminal offenses of aggravated larceny were analyzed, and a sample for the survey included 193 perpetrators and 174 victims, the reason being that several individuals participated in the commission of certain criminal offenses, and there were more victims in some cases.

\subsection{Instrument}

The data necessary for the realization of this research were collected using, for this purpose, a specially prepared questionnaire. The survey questionnaire contained a total of 67 variables that were divided into 3 units: general data on the criminal offense, evidentiary actions conducted during the investigation of the criminal offense, the suspect (examination under art. 208a of the CPC and information on the suspect) and the variables related to the victim.

The following variables were used in making this research:

1. Conducted on-site investigation during criminal investigation of aggravated larceny,

2. Temporary confiscation of items in criminal investigation of aggravated larceny,

3. Temporary seizure of surveillance camera videos - useful information about the perpetrator,

4. The type of expertise conducted in the criminal offense of aggravated larceny,

5. Checking for the establishment of electronic communication and telecommunications contact,

6. Collecting information from a person in their capacity as a citizen prior to her/ his becoming a suspect (Art. 208. CPC),

7. Consuming the rights to a defense attorney by the suspects,

8. The suspect's defense and their answers to the questions,

9. The statement of the suspect,

10. The search of the suspect's home and other places - the finding of objects and leads referring to the suspect,

11. The search of the suspect's movable property - the finding of objects and indications referring to the suspect, 
12. Identification of the suspects as a conducted evidentiary action,

13. Decision of the competent state attorney.

These variables have been selected for the purpose of realizing the aim of the research, moreover, for the purpose of gaining insight into certain ways of proving criminal offenses of aggravated larceny, with particular reference to the interrogation of the suspect under art. 208a of the CPC and the significance of the evidence thus obtained, for proving the committed criminal offense.

\subsection{Method of conducting research}

In February 2019, the Ministry of the Interior of the Republic of Croatia had given consent to conduct the research, i.e. to collect and use the collected data from the areas of all County Police Administrations in the Republic of Croatia. A special consent of the Ethics Commission was not required, although it usually is for research that involves people as respondents, since it was a research based on the analysis of secondary data. In terms of general ethical principles in scientific research, the anonymity of perpetrators and victims was respected, in that the identification data were not included in the questionnaires. The survey was conducted in March 2019, in a way that survey questionnaires were filled based on insights into police records.

\subsection{Data processing}

After completion of data collection, the data from the survey questionnaires were entered into the database in the SPSS statistical software program (version 16.0), and after the completion of data entry, the logical control was performed. Descriptive statistics were used for the purpose of the defined research goal.

\section{RESULTS OF RESEARCH}

\subsection{Specific evidentiary actions conducted during the inquiry into the criminal offense of aggravated larceny}

In the chapter of "Specific evidentiary actions conducted during the inquiry into the criminal offense of aggravated larceny", the authors will use a descriptive method to explain which evidentiary actions were conducted by the police officers, after learning about committed criminal offence, in order to find the perpetrator.

Thus, one of the first evidentiary actions undertaken after learning about the committed criminal offense, is the inquiry. During inquiry, the facts are determined or clarified by observation using one's own senses or by using aids (Art. 304. CPC). 
In the analyzed cases, it is evident that the on-site investigation was conducted in $84.4 \%$ of cases. If an evidentiary action of on-site investigation was not conducted by the investigative team, the scene of the event was examined, and in 3\% of the cases, neither the on-site investigation, nor the examination of the scene was conducted.

Graph 2. Evidentiary action of on-site investigation of criminal offence of aggravated larceny

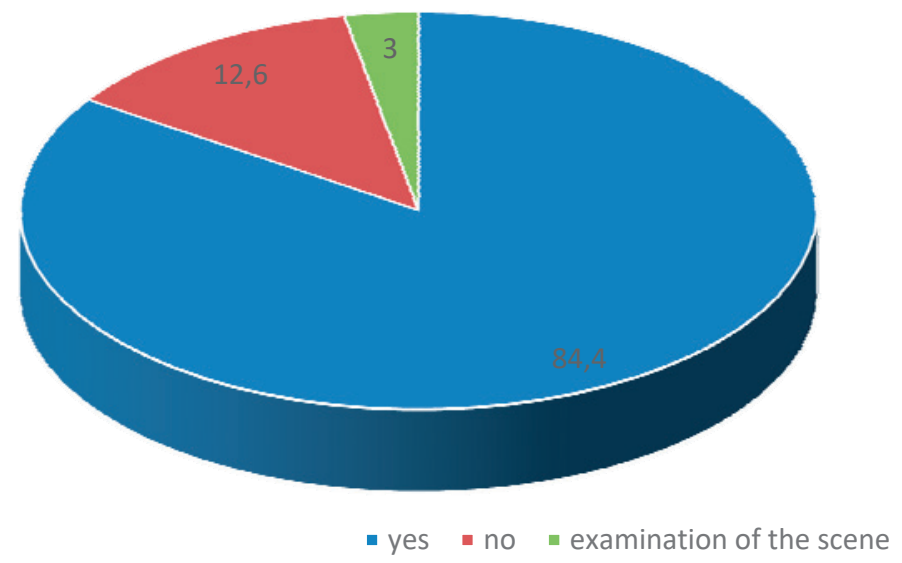

Source: authors' research

Temporary seizure of objects is also directly related with the evidentiary action of on-site investigation. In addition to objects being temporarily seized during the conduct of on-site investigation, they are also temporarily seized during criminal investigation. Thus, during the course of the criminal investigation, the police officers will temporarily seize objects that are to be confiscated as pursuant to the criminal law or are objects that may serve to determine the facts in the procedure (Art. 261., para. 1. of the CPC). From the results of the survey it is evident that police officers during the course of conducting on-site investigation, as well as during the criminal investigation, in $47.9 \%$ of the cases temporarily seized the items. 
Graph 3. Temporary seizure of objects in criminal investigation of criminal offence of aggravated larceny

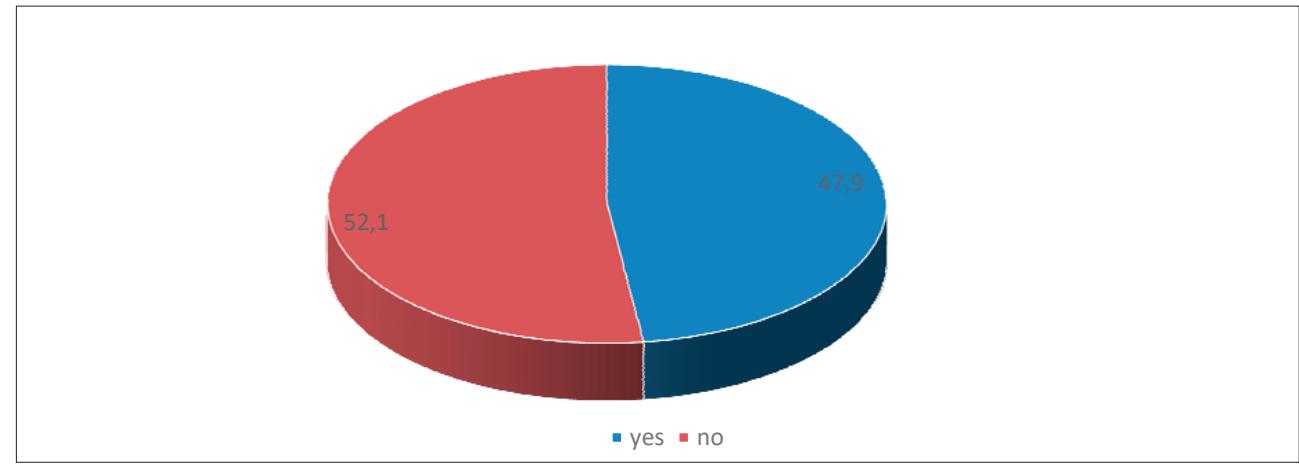

Source: authors' research

In the context of the evidentiary action of temporary seizure of an object, it should be noted that the police officers, during the course of the criminal investigation of aggravated larceny, conducted fieldwork inquires, during which they collected information from citizens who were likely to have knowledge of the circumstances of the perpetration of the criminal offense (Art. 36 para. 1., the Police Duties and Powers Act, Official Gazette of the Republic of Croatia, No. 76/09, 92/14, hereinafter PDPA). From the results of the research, $86.8 \%$ of police officers conducted fieldwork. Furthermore, surveillance camera videos were temporarily seized during conduct of fieldwork inquiries. The relative proportion of cases in which police officers temporarily seized surveillance camera videos, in total number of cases $(\mathrm{N}=167)$, was $29.3 \%$. The results of the survey show that, in the total number of cases observed, the relative proportion of those cases in which useful information about the suspect was obtained via videos of temporarily seized video cameras was $22.8 \%$.

Graph 4. Temporary seizure of surveillance camera videos - useful information about the perpetrator

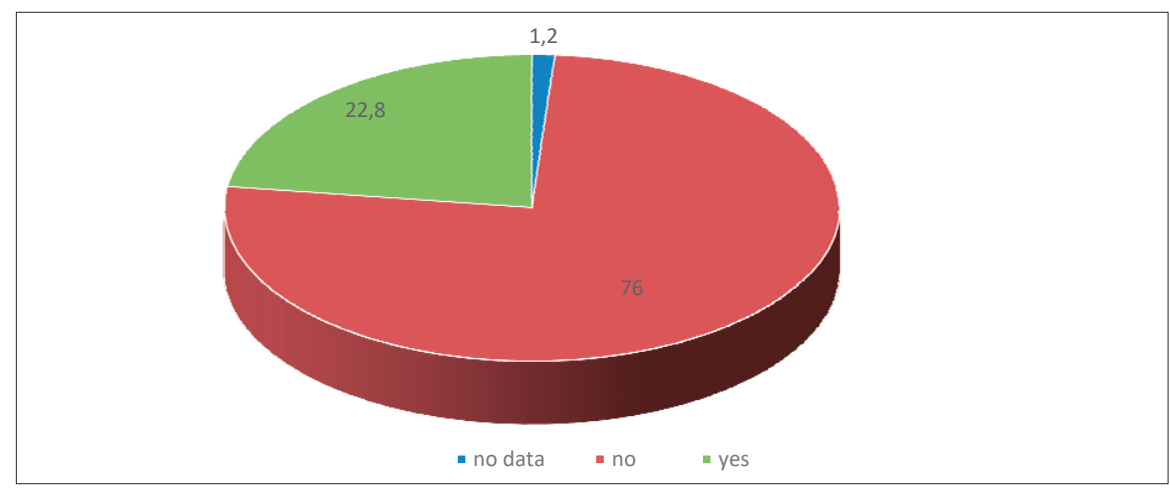


Source: authors' research

In addition to the evidentiary action of on-site investigation, ie primarily the temporary seizure of objects and traces, the evidentiary action of expertise is conducted. Expertise is conducted when it is necessary, for determination or examination an important fact, to gain an opinion or an assessment of a person who has the necessary expertise or skill in determining or evaluating such $s$ fact (Art. 308. CPC).

From the conducted research it is evident that in most cases no expertise was conducted (88.0\%). Of the total observed criminal offenses $(\mathrm{N}=167)$, in $12.0 \%$ of the cases the expert's opinion was sought out. Given the found objects and traces during the conduct of the evidentiary action of on-site investigation, but also during the inquiry, in relation to the total number of committed criminal offenses, biological expertise was most commonly conducted $(5.4 \%)$, followed by biological and dactyloscopic expertise $(2.4 \%)$ and only dactyloscopic experise $(1.8 \%)$. In one case, three experts' opinions were sought out (including biological, dactyloscopic and chemical-physical expertise) and in one case, two experts' opinions were sought out (both biological and mechanoscopic). In two cases only mechanoscopic expertise was conducted.

Of the total of 20 cases in which expertise was conducted, in $50 \%$ of those, the expertise led to information about the particular perpetrator of the criminal offense, while only in one case, no data were found, on whether the results of expertise resulted in gaining information about the perpetrator. 
Graph 5. Type of expertise conducted for criminal offence of aggravated larceny

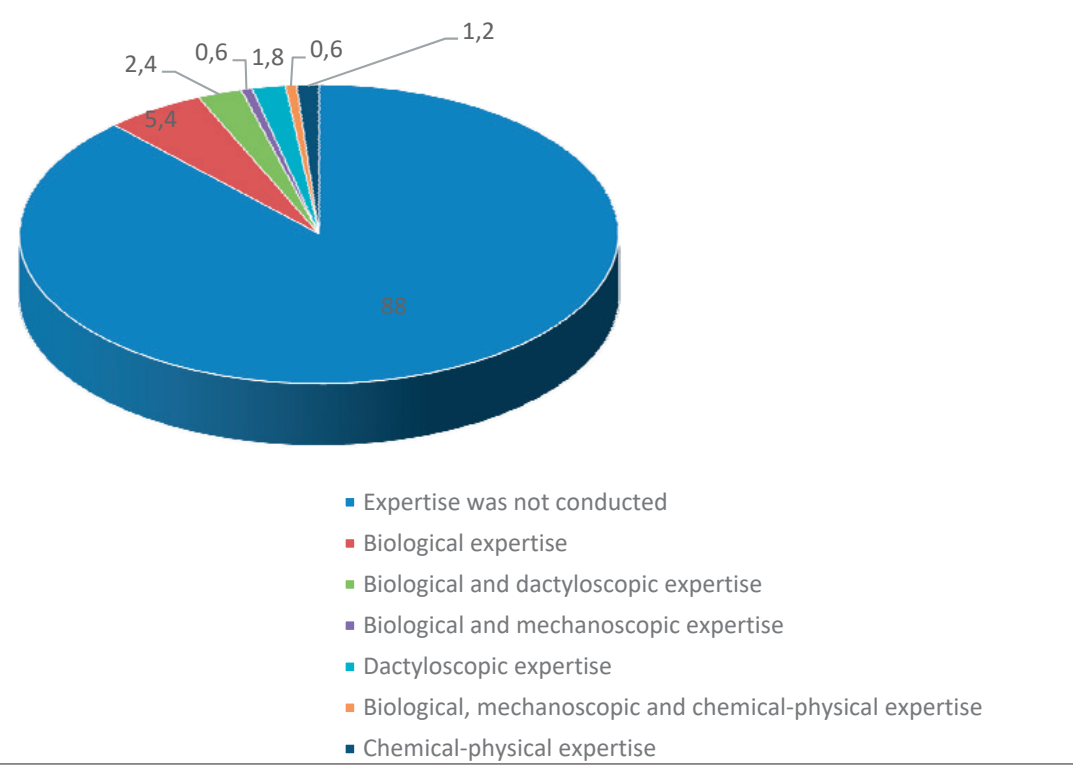

Source: authors' research

One of the police powers is to verify the establishment of electronic communications. Police officers may, for the purpose of preventing and detecting criminal offenses prosecuted ex officio and perpetrators of such criminal offences, request verification of the identity, duration and frequency of communication with certain electronic communication addresses from the communication service provider (Art. 68. para. 1. PDPA). In addition to this police authority, police officers may, if the conditions set out in art. $339 \mathrm{a} \mathrm{CPC}^{6}$ are met, request verification of establishment of telecommunication contact. From the results of the research, it is apparent that the police officers had, in $20.4 \%$ of cases under art. 68. PDPA, requested verification of electronic communication establishment. In $0.6 \%$ of cases, in addition to art. 68., based on a court order of the judge of investigation, the police officers had also requested the verification of the establishment of a telecommunication contact (Art. 339a CPC). Out of the total number of cases analyzed,

6 Art. 68. PDPA prescribe the powers of verification of establishing electronic communications, while Art. 339a of the CPC provides for the verification of the establishment of a telecommunication contact. The aforesaid actions are similar in substance but they are differentiated in so that the action referred to in art. 68. The PDPA can be undertaken without a warrant and towards the users of telecommunication services who are not registered, while the action referred to in art. 339a CPC requires a court order, it is undertaken towards the registered users and it's results can be used as evidence in the process. The results of the action under art. 68. of the PDPA remain mainly operational 
in $10.8 \%$ of cases, police officers gained useful knowledge of the perpetrator of aggravated larceny.

Graph 6. Verification of establishment of electronic and telecommunication communication

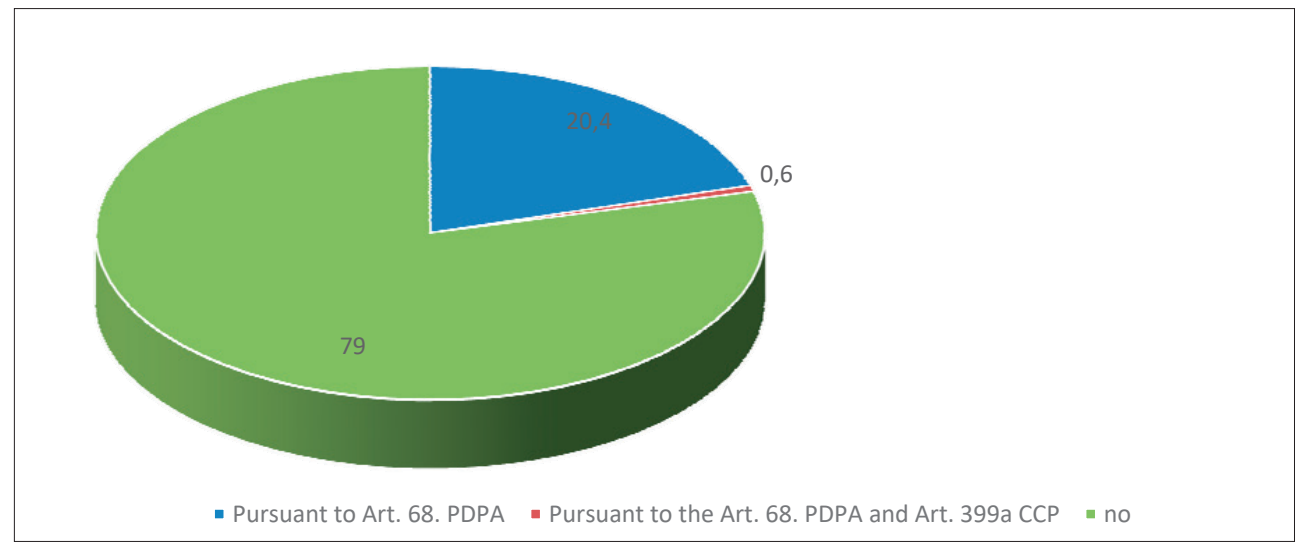

Source: authors' research

\subsection{Specific actions taken against a person for whom there are grounds for suspicion of having committed a criminal offense of aggravated larceny}

In this chapter, the authors will, using a descriptive method, present the results of the research regarding particular police actions, as well as the evidentiary actions that police officers applied toward the person for whom there were grounds for suspicion that they were the perpetrator of a particular criminal offense of aggravated larceny. Considering that a number of persons participated in the perpetration of aggravated larceny in certain cases analyzed in this chapter, the results of the research are compared with the total number of persons involved in the commission of the criminal offense $(\mathrm{N}=193)$.

Considering that police officers, based on art. 208. CPC, may collect information from citizens in the course of the inquires, from the data obtained by the conducted research it is apparent that the police officers collected the information from a citizen in $20.7 \%$ of cases, before they became a suspect. From the obtained data, it is evident that in the total number of perpetrators, the relative proportion of those for whom the grounds for suspicion that they are a person who committed or participated in the perpetration of a criminal offense were raised during collection of information from a citizen (Art. 208., para. 5. CPC), amounted to $18.7 \%$. Other suspects, from the analyzed sample, of the investigation were either called as suspects (Art. 208a, para. 1. of the CPC) or were arrested at the place of perpetration of a criminal offense under the art. 107. CPC. 
Klier, Kondor-Langer, Gluščić $(2018,462)$ on a sample of Zagreb County Police Administration $(\mathrm{N}=141)$ cases, in which an interrogation of a suspect was conducted, pursuant to art. 208a of the CPC, found that police officers had collected information from only $5 \%$ of persons before them becoming suspects.

Graph 7. During collection of information from a citizen, the grounds for suspicion that the person comitted or was involved in commission of aggravated larceny, were raised

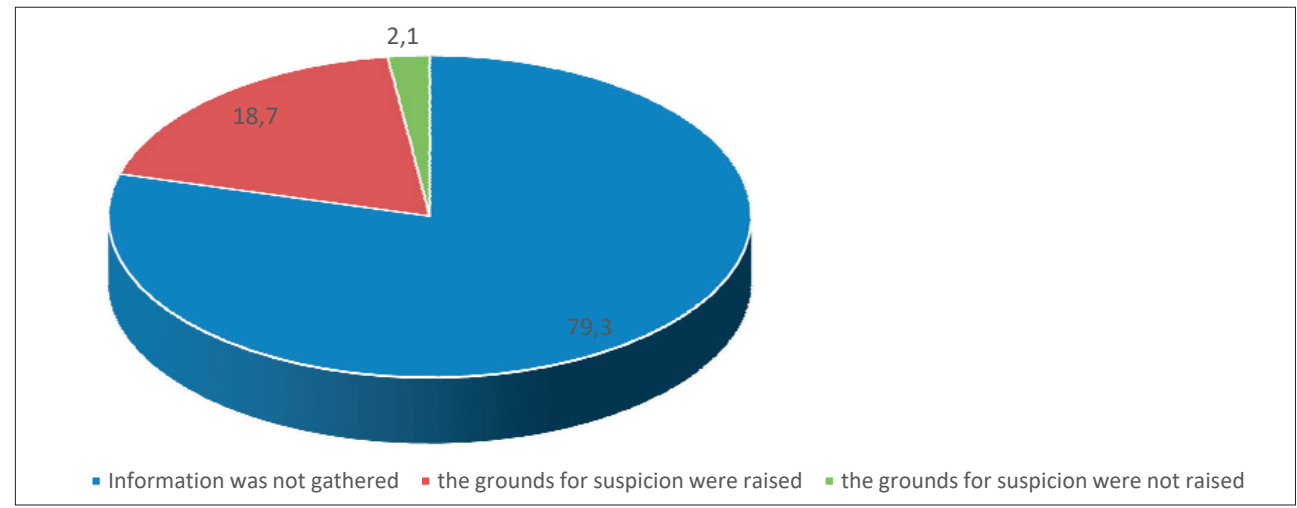

Source: authors' research

Considering that the suspect prior to the interrogation, pursuant to art. 208a $\mathrm{CPC}$, must understand and receive a written instruction on their rights set forth in art. 208a para. 2. of the CPC, which contains, amongst other things, the right to a defense attorney, the results of the conducted research show that 32 suspects have used their right to a defense attorney. Out of 32 cases, the defense attorney did not show up in 2 cases. Out of a total of 32 cases, in half of the cases the defense attorney was selected by the suspect by their own choice, while in the second half the suspects hired the defense attorney from the list of attorneys at the Croatian Bar Association. In the majority of cases, the suspects did not consume their right to a defense attorney after being given an instruction (80.3\%). From the obtained data, it is apparent that 5 suspects were not interrogated under art. 208a of the CPC, and in 1 case there is no information on the suspect's consumption of right to a defense attorney. It should be noted here that the 20 suspects were obliged to have a defense attorney since they were underage. During the interrogation of only one suspect, a competent state attorney was present.

In their research, Klier, Kondor-Langer, Glušcic (2018) found that $19.4 \%$ of suspects consumed their right to a defense attorney during the interrogation pursuant to art. 208a CPC.

Graph 8. Consumation of the suspect's right to a defense attorney 


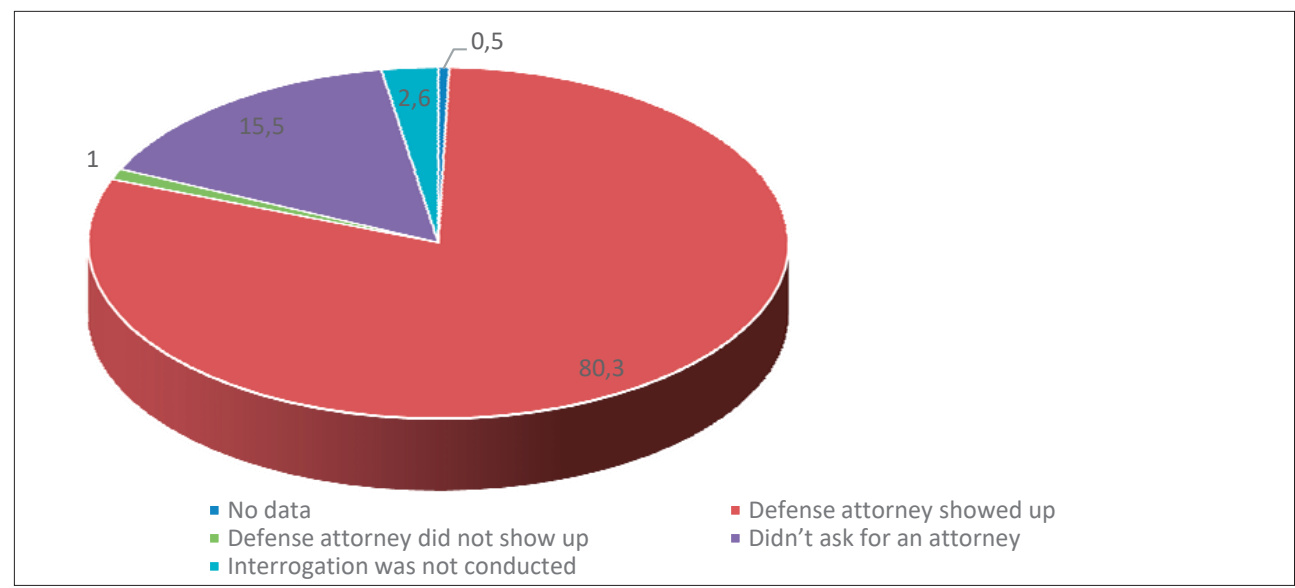

Source: authors' reserch

Given that the suspect, during the interrogation pursuant to the art. 208a of the CPC, should be enabled to disclose, in an unobstructed manner, all the circumstances regarding the charges against them and to present all the facts that serve for their defense, regardless of whether they wish to answer the questions (Art. 276. para. 3. and 4. of the CPC), such data were also analyzed during the research. From the data obtained, it is evident that the relatively largest number of suspects put forth their defense claims and had answered questions (80.3\%), then $13 \%$ who did not answer the questions. This is followed by $3.6 \%$ of the suspects who stated their defense claims, but did not answer the questions asked.

Concerning the defense claims and answering the questions, Klier, KondorLanger, Gluščić $(2018,463)$ on their sample survey, found that $47.5 \%$ of the suspects actively stated their defense and answered the questions, while $25.5 \%$ of the suspects actively gave their defense claims, but did not answer the questions. 
Graph 9. Suspects defense claims and answers to the questions

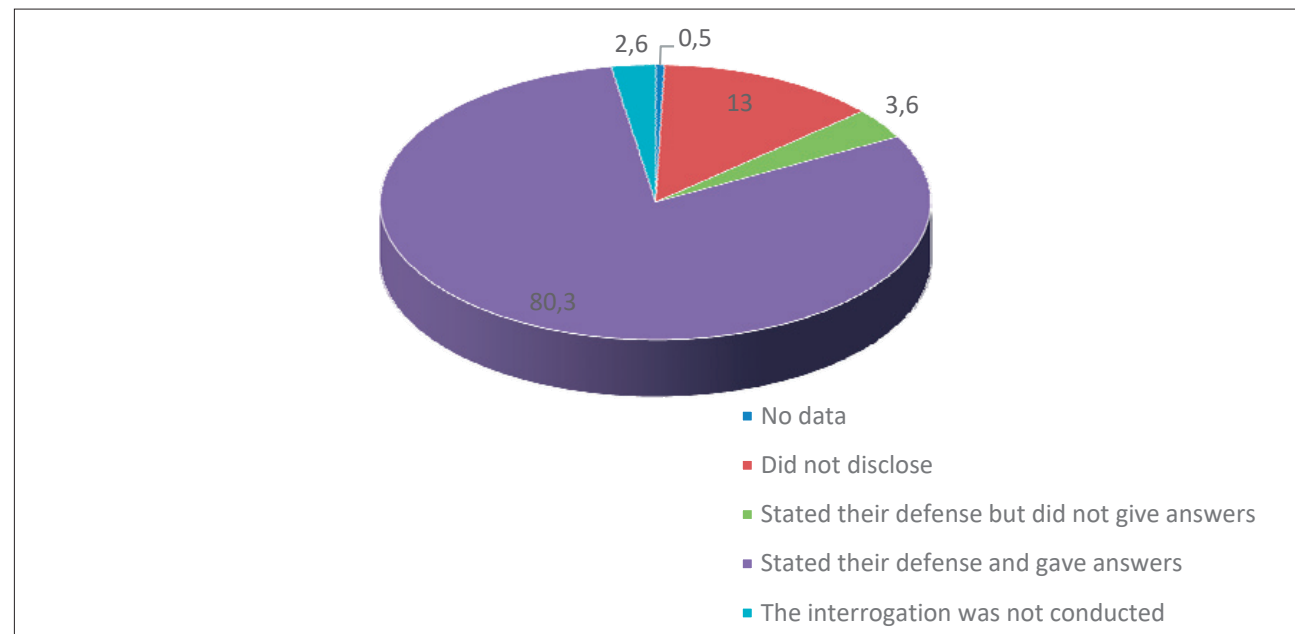

Source: authors' research

During an interrogation, a suspect can defend themselves by remaining silent, that is, by not responding or can deny the criminal offense he is charged with, or can confess. From the obtained data, it is apparent that the relatively high number of suspects, during the interrogation pursuant to the on art. 208a of the CPC, confessed to committing of aggravated larceny (75.1\%). After the suspects who confessed the perpetration of the criminal offense, the suspects who defended by remaining silent or by not responding $(13.0 \%)$ are followed by suspects who denied committing aggravated larceny $(8.8 \%)$. It should be noted here that 5 suspects were not questioned under art. 208a CPC, and in one case there was no information about the way the suspect conducted their statement. In all cases where a suspect's interrogation was conducted, pursuant to art. 208a CPC, in all instances the interrogation was recorded by an audio video device (Art. 208a para. 6. of the CPC).

Klier, Kondor-Langer, Gluščić $(2018,466)$ found that in the criminal offense against property, the highest proportion of suspects are those who did not respond $(34.2 \%)$ and those who confessed $(34.1 \%)$, as well as those who denied committing the offence $(37.3 \%)$. Such results were expected as the largest share of the observed sample regarded criminal offenses against property. 
Graph 10. Suspect's statement

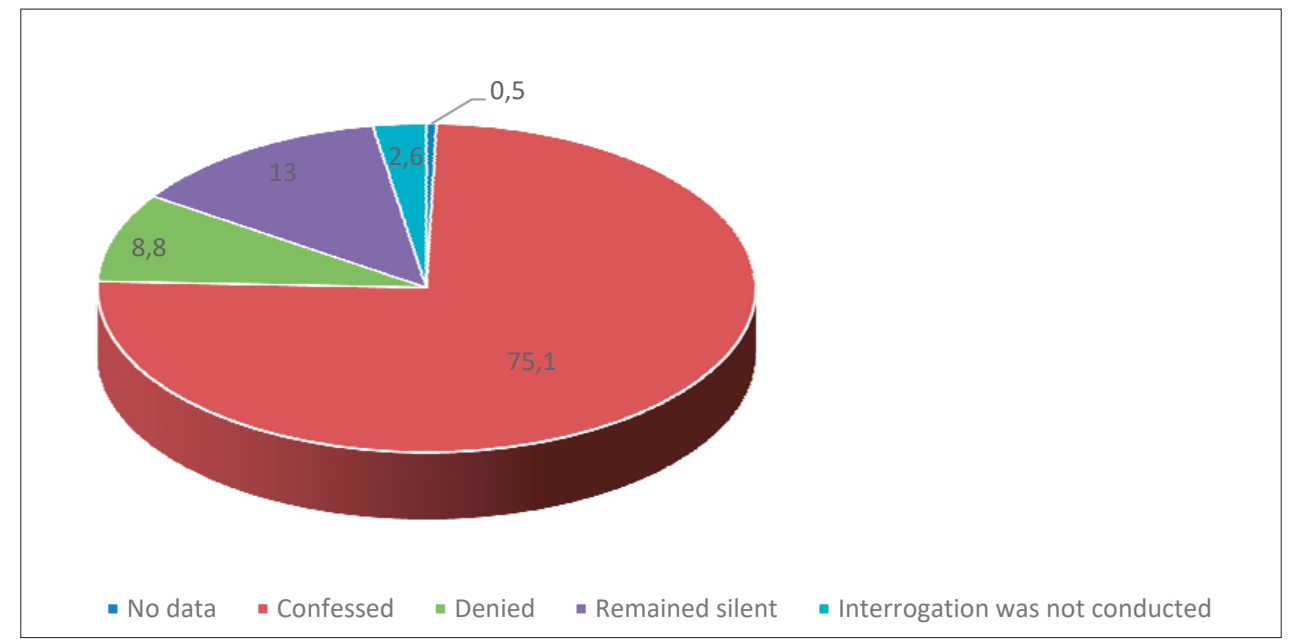

Source: authors' research

Where it is probable that the objects or marks relevant to the criminal proceedings are in a certain area, a search of a home or other place, vehicles and other movable property of that person will be conducted, as well as a search of a particular person (Art. 240., para. 2. CPC). From the analyzed data, it is evident that police officers or investigators conducted searches of the suspect's home and other premises during the investigation in $27.5 \%$ of cases. If the obtained data related to the search of the suspect's home and other premises are viewed in relation to the total number of suspects $(\mathrm{N}=193)$, it is evident that in $16.6 \%$ of the cases where the search of the home and other premises was conducted, objects and traces found, indicated that the suspect indeed committed the criminal offense of aggravated larceny, due to which the search was ordered by the investigation judge. In a somewhat smaller number of cases, in which the search of the suspect's home and other premises, was conducted, no objects and traces that would connect the suspect with the committed criminal offense were found $(10.4 \%)$. Here it is necessary to note that in $2,1 \%$ of cases no data were found to confirm or deny that the found objects and traces could link the suspect to the criminal offense of aggravated larceny. 
Graph 11. Evidentiary action of search of the suspect's home and other premises - instances of found traces and marks that point to the suspect

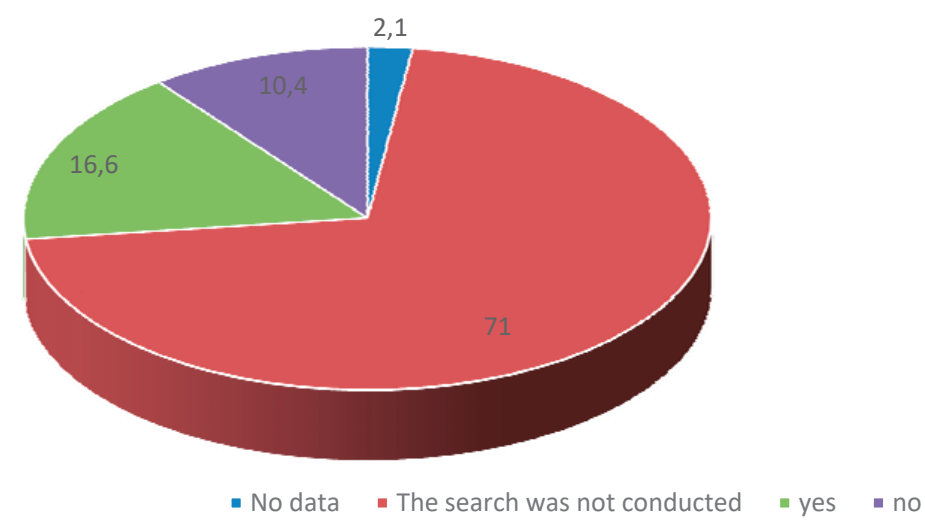

Source: authors' research

In addition to the evidentiary action of the search of the suspect's home and other places, police officers also conducted the search of movable property in the $10.4 \%$ cases. In all cases where the search of a moving property was conducted, the suspect's personal vehicle was searched. In the relatively large number of cases in which the search of a suspect vehicle was conducted, police officers or investigators found the objects and traces connecting the suspect with the criminal offense of aggravated larceny $(7.3 \%)$.

Graf 12. Evidentiary action of search of suspect's mobile property - instances of found traces and marks that point to the suspect

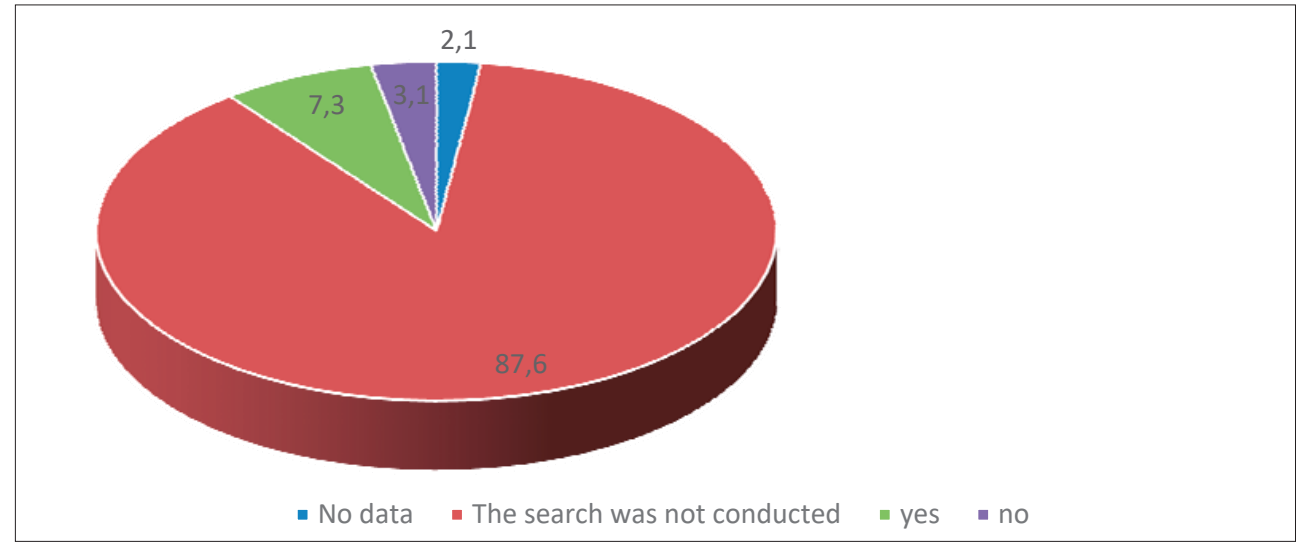

Source: authors' research 
In addition to conducting search during the criminal investigation, based on the order of the competent state attorney, if, for example, a witness or a victim have seen the suspect, the identification of the person or the suspect may also be conducted. Identification is the recognition of the identity of a person, object, space, sound, movement or other features observed by the defendant or witness, which is then determined by comparison to another person, object, space, sound, movement or other feature (Art. 301. para. 1. CPC).

From the obtained data in the research, the evidentiary action of identification of suspects was conducted in $8.3 \%$ of cases. The results of identification can be positive, which means that the person has identified the suspect, or may be negative, which means that the person did not recognize the suspect. In addition to these two results, in the criminalistic sense, it is also necessary to mention the result of the identification, i.e. a separation. We are talking about such result in cases where the witness is not completely sure that he recognizes or does not recognize the person shown. This result in the evidentiary sense does not have any value, however it can give some identification to police officers for further investigation. The obtained results showed that in $6.7 \%$ of cases witnesses identified suspects as perpetrators of aggravated larceny. In $0,5 \%$ of cases, the suspect was not recognized while in only $1 \%$ of the cases separation occurred.

Graph 13. Evidentiary action of identification of the suspect

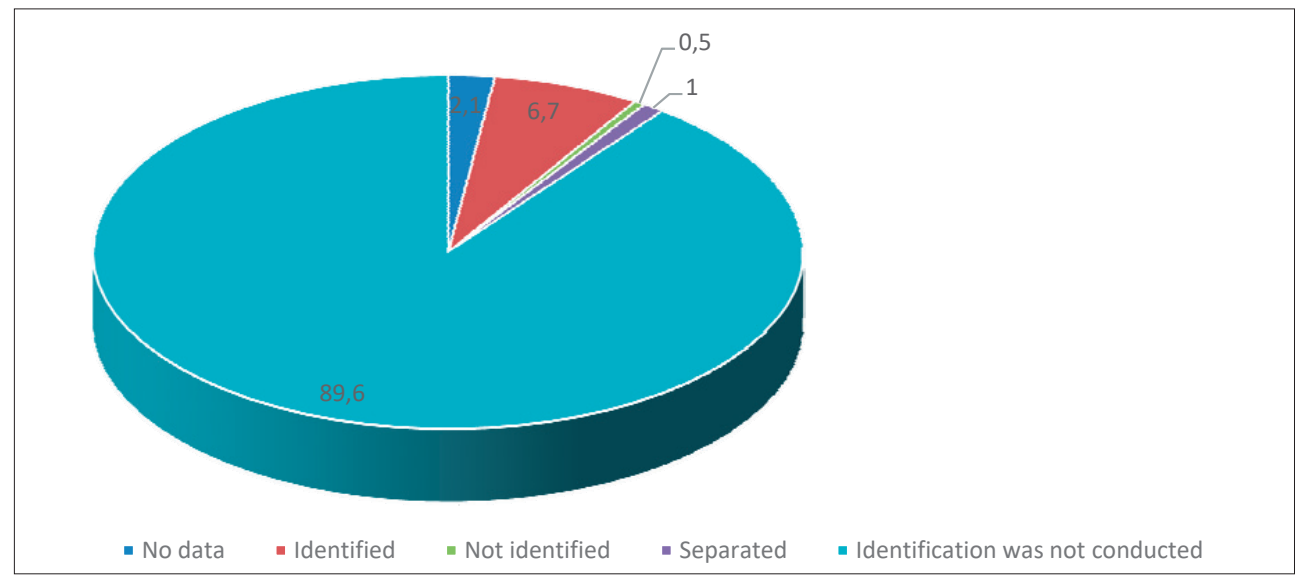

Source: authors' research

Upon completion of the criminal investigation, the police officers, if they have sufficient evidence against the suspect, file a criminal report to the competent state prosecutor's office. Upon receipt of the criminal report, the State Attorney's Office may dismiss the criminal charges for one of the reasons set out in art. 206. para. 1. of the CPC or in further proceedings, when the state of affairs is sufficiently 
resolved, indict the suspect. The results of the conducted research showed that in $58.0 \%$ of the analyzed cases the perpetrator was indicted. For $36.8 \%$ of the cases there is no data on the indictment or rejecting criminal charges while $5.2 \%$ of criminal reports have been dismissed.

If the suspect's interrogation, from the conducted survey, is considered in relation to the obtained data related to the indictment, ie the dismissal of the criminal charges, it can be seen that, in a relatively large number of cases, the State Attorney's Office filed an indictment in those cases where the suspect, during a police interrogation, pursuant to art. 208a of the CPC, confessed the criminal offense (58.6\%). In only 5.5\% of cases, the State Attorney's Office dismissed the criminal complaint, even though the suspect had confessed to the criminal offence during police interrogation, as pursuant to art. 208a of the CPC. In the other $35.9 \%$ of cases there is no information as to whether the indictment was raised in the concrete case, which is actually one of the limitations of the conducted survey.

Graph 14. The decision of the competent state attorney

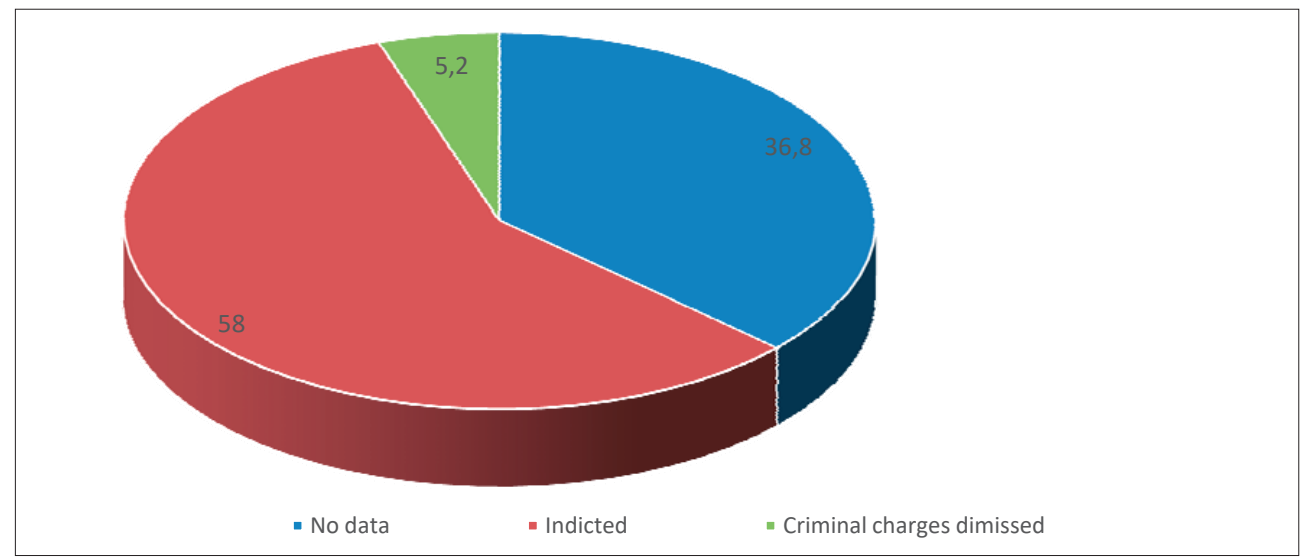

Source: authors' research

\section{CONCLUSION OF RESEARCH RESULTS}

The authors of this paper have divided the results of the research into two units. The first encompasses police officers' actions, primarily evidentiary actions undertaken during the inquires, and after learning of the perpetration of aggravated larceny. The second part covers the results of the interrogation of the suspect pursuant to art. 208a CPC, but also the evidentiary actions conducted against the suspect, as well as the data relating to the decision of the competent state attorney regarding the filed criminal charges. 
The limitations of this research are related to the lack of particular data in some analyzed cases, which is why the category "no data" was formed.

The aim of the conducted research is to gain insight into certain ways of proving criminal offenses of aggravated larceny, with special reference to the suspect's interrogation based on art. 208a of the CPC and the importance of such evidence to prove the perpetrated criminal offense.

Both hypotheses set for the purpose of this research; H1: In the commission of offenses of aggravated larceny other than the suspect's interrogation based on art. 208a CPC there is little other material evidence and hypothesis H2: Relatively small number of suspects consume their right to a defense attorney during the interrogation pursuant to art. 208a CPC, have been confirmed.

This is supported by the following:

- Among all evidentiary actions conducted by the police officers after the perpetration of the criminal offense of aggravated larceny, an urgent evidentiary action of on-site investigation has to be mentioned. It was undertaken in $84.4 \%$ of the cases. On-site investigation is followed by expertise which has been conducted in $12 \%$ of the cases, among which the most commonly conducted was biological expertise (5.4\%),

- in the course of conducting an on-site investigation, but also during inquires, in $47.9 \%$ of the cases, the police have temporarily seized objects. In $86.8 \%$ of cases, fieldwork was conducted during which police officers temporarily seized surveillance cameras videos (29.3\%). In the total number of cases observed, the relative proportion of cases in which, by means of temporary seizure of surveillance camera videos, in $22.8 \%$ cases it resulted in obtaining useful facts about the perpetrator,

- police officers have sought verification of the establishment of electronic communications in $20.4 \%$ of cases under art. 68. PDPA, and from the total number of cases analyzed, in $10.8 \%$ of cases, it resulted in obtaining useful facts about the perpetrator of the criminal offense of aggravated larceny,

- the police officers collected the information from a citizen in $20.7 \%$ of cases before they bacame a suspect. In $18.7 \%$ of the cases, there were grounds for suspicion that the person committed or participated in the commission of a criminal offense,

- in most cases, the suspects did not consume (80.3\%) their right to a defense attorney after being instructed about the said right. It is evident that 32 suspects have used their right to a defense attorney, of which, 2 attorneys did not show up. It should be noted that 20 suspects were obliged to a defense attorney since 
they were underage suspects. In half of the cases, the suspects chose a defender in their own choice, while the second half the suspects hired the defense attorney from the list of attorneys at the Croatian Bar Association. In 2.6\% of the cases an interrogation pursuant to the art. 208a CPC was not conducted. In only one case during the interrogation, a state attorney participated,

- during the interrogation pursuant to art. 208a CPC, the relatively large number of suspects stated their defense and has answered questions (80.3\%), while $13 \%$ of the suspects did not respond. They are followed by 3.6\% of the suspects who stated their defense, but did not answer the questions,

- the relatively large number of suspects confessed the perpetration of aggravated larceny $(75.1 \%)$. After those suspects who confessed the perpetration of the criminal offense, the suspects who defended by remaining silent or who did not respond followed $(13.0 \%)$, while in $8.8 \%$ of cases the suspects denied the accusation of aggravated larceny,

- during the criminal investigation, police officers or investigators conducted a search of the suspect's home and other premises in $27.5 \%$ of cases. Compared to the total number of suspects $(\mathrm{N}=193)$, it is apparent that in $16.6 \%$ of cases, items and traces were found that indicated that the suspect committed a serious offense of aggravated larceny. In $10.4 \%$ of cases, a search of movable property was conducted, and in all cases it was a search of the suspect's personal vehicle. In the relative majority when a a search of the suspect's vehicle was conducted, police officers or investigators found objects and traces linking the suspect with the offense of aggravated larceny $(7.3 \%)$.

- the identification of the suspect was conducted in $8.3 \%$ of the cases and witnesses have identified suspects as perpetrators of aggravated larceny in $6.7 \%$ of cases.

Also, the results of the conducted research showed that $58.0 \%$ of the analyzed cases resulted in an indictment against the perpetrator. For $36.8 \%$ of the suspects there is no data on the indictment or on rejecting criminal charges, while $5.2 \%$ of the criminal charges have been dismissed.

If the suspect's interrogation, from the conducted survey, is considered in relation to the obtained data related to the indictment, ie the dismissal of the criminal charges, it can be seen that, in a relatively large number of cases, the State Attorney's Office filed an indictment in those cases where the suspect, during a police interrogation, pursuant to art. 208a of the CPC, confessed the criminal offense (58.6\%). In only 5.5\% of cases, the State Attorney's Office dismissed the criminal complaint, even though the suspect had confessed to the criminal offence during police interrogation, as pursuant to art. 208a of the CPC. In the other $35.9 \%$ of 
cases there is no information as to whether the indictment was raised in the concrete case, which is actually one of the limitations of the conducted survey.

Finally, it should be mentioned that this work is primarily intended for the employees of the Ministry of the Interior, but also to all other practitioners and theorists who deal with the suspects. From a practical point of view, the work should give a certain amount of input for consideration of possible improvements of conduct of certain actions during the investigation of aggravated larceny crimes.

\section{REFERENCES}

\section{BOOKS AND ARTICLES}

1. Burić, Z.; Karas, Ž., Prilog raspravi o dvojbama veznima uz novu definiciju osumnjičenika $i$ radnju njegova ispitivanja, Hrvatski ljetopis za kaznene znanosti i praksu, Vol.n24, No. 2, Zagreb 2017, p. 443-482

2. Deljkić, I., Heurističke i silogisticke determinante istraživanja alibija u Kantonu Sarajevo, Kriminalističke teme 3-4, 2010, p. 99-117

3. Gluščić, S.; Kondor-Langer, M., The impact of Amandmens and Supplements to the Criminal Procedure Law in determining, discussing, and proving the General criminality offenses, EU and Comparative Law Issues and Challenges, Osijek, 2018, p. 449-467

4. Ivičević Karas, E.; Burić, Z., Bonačić, M., Unapredenje procesnih prava osumnjičenika i okrivljenika u kaznenom postupku: pogled kroz prizmu europskih pravnih standarda, Hrvatski ljetopis za kazneno pravo i praksu, Vol. 23, No. 1, 2016, p. 11-58

5. Ivičević Karas, E.; Burić, Z.; Bonačić, M., Prava obrane u različitim stadijima hrvatskog kaznenog postupka: rezultati istraživanja prakse, Hrvatski ljetopis za kazneno pravo i praksu, Vol. 23, No. 2, 2016, p. 509-545

6. Karas, Ž.; Štrk, D.Izdvajanje nezakonitih materijalnih dokaza u poredbenom kaznenom postupovnom pravu, Zagrebačka pravna revija Vol. 2, No. 2, 2013, p. 185-212

7. Klier, D.; Kondor-Langer, M.; Gluščić, S., Policijska i državnoodvjetničcka praksa u ispitivanju osumnjičenika, Hrvatski ljetopis za kazneno pravo i praksu, Vol. 25, No. 2, 2018, p. 447-475

8. Novokmet, A.; Vinković, Z., Police Interrogation of the Suspect in Croatia After the Implementation of the Directive 2013/48/EU - State of Play and Open Questions, EU and Comparative Law Issues and Challenges, Osijek, 2018, p. 418- 448

\section{EU LAW}

1. Directive 2013/48/EU on the right of access to a lawyer in criminal proceedings and in European arrest warrant proceedings, and on the right to have a third party informed upon deprivation of liberty and to communicate with third persons and with consular authorities while deprived of liberty, OJ L 294 [http://eur-lex.europa.eu/legal-content/HR/ TXT/PDF/?uri=CELEX:32013L0048\&from=HR] Accessed 01.03.2019 


\section{LIST OF NACIONAL REGULATIONS, ACTS AND COURT DECISIONS}

1. Amendments of the Criminal Procedure Code, Official Gazette of the Republic of Croatia, No. $70 / 17$

2. Criminal Code, Official Gazette of the Republic of Croatia, No. 125/11, 144/12, 56/15, $61 / 15,101 / 17,118 / 18$

3. Criminal Procedure Code, Official Gazette of the Republic of Croatia, No. 152/08, 76/09, 80/11, 91/12 - Decision Constitutional Court of Croatia, 143/12, 56/13, 145/13, 152/14 and $70 / 17$

4. Police Duties and Powers Act, Official Gazette of the Republic of Croatia, No. 76/09, 92/14

\section{WEBSITE REFERENCES}

1. Ministry of the Interior of the Republic of Croatia, General Secretariat, Department for Strategic Planning, Analysis and Development, Survey of Basic safety Indicators for year 2018, [https://mup.gov.hr/UserDocsImages/statistika/2018/Travanj/Statisticki\%20pregled\%20 2017.pdf] Accessed 08.05.2019

2. Ministry of the Interior of the Republic of Croatia, General Secretariat, Department for Strategic Planning, Analysis and Development, Survey of Basic safety Indicators for year 2018, [https://mup.gov.hr/UserDocsImages/statistika/2018/Statisticki\%20pregled\%20 temeljnih\%20sigurnosnih\%20 pokazatelja $\% 20$ i $\% 20$ rezultata $\% 20$ rada $\% 20$ u $\% 20$ 2018.\%20godini.pd] Accessed 18.03.2019

3. [http://eur-lex.europa.eu/legal-content/HR/TXT/PDF/?uri=CELEX:32013L0048\&from= HR.] Accessed 01.03.2019 